\title{
Stan normalizacji w zakresie systemów jakości, kwalifikacji personelu oraz badań odbiorczych urządzeń w technologiach natryskiwania cieplnego
}

\author{
Standardization in the field of quality systems, \\ personnel qualifications and testing of equipment \\ in thermal spray technologies
}

\section{Streszczenie}

W artykule dokonano przeglądu ustanowionych Polskich Norm decydujących o zapewnieniu wysokiej jakości procesu wytwarzania powłok natryskiwanych cieplnie. Przedstawiono normy dotyczące zasad wprowadzania systemów jakości w zakładach wykonujących proces natryskiwania cieplnego, normy dotyczące kwalifikacji personelu wykonującego oraz nadzorującego proces natryskiwania cieplnego oraz normy dotyczące badań odbiorczych urządzeń do natryskiwania cieplnego. Przedstawiono krótki opis każdej z tych norm.

Słowa kluczowe: system jakości, kwalifikacje personelu, natryskiwanie cieplne

\begin{abstract}
The paper reviewed the set of Polish Standards determining high quality of thermally sprayed coatings. The study presents the standards on quality assurance measures for thermal spray instalations, personel qualification (both thermal sprayer and supervising personel), testing of components and accompanying speciments and quality assurance measures. A short description of each of these standards was given.
\end{abstract}

Keywords: quality system, personnel qualifications, thermal spraying

\section{Wstęp}

Proces natryskiwania cieplnego stosowany jest powszechnie w wielu gałęziach przemysłu do nanoszenia powłok odpornych na korozję, w regeneracji części maszyn, do wytwarzania powłok na nowych częściach maszyn o szczególnie wysokich właściwościach oraz do wytwarzania powłok dekoracyjnych. Przy tak szerokim zastosowaniu powłok natryskiwanych cieplnie bardzo ważne jest zapewnienie możliwie wysokiej jakości wytwarzanych wyrobów.

W celu otrzymania, zgodnej z wymaganiami, wysokiej jakości powłok konieczne jest monitorowanie wszystkich czynników biorących udział w procesie natryskiwania cieplnego, gdyż proces ten cechuje duża trudność w kontroli przebiegu poszczególnych etapów produkcji, których prawidłowość gwarantuje wysoką jakość. Jakości produktu nie zapewni tylko kontrola ostateczna, musi ona wynikać z zapewnienia jakości podczas całego procesu produkcyjnego.

W związku z tym należy znormalizować wymagania, jakie muszą spełniać materiały i urządzenia użyte podczas procesu produkcyjnego oraz cały proces od przygotowania powierzchni podłoża do obróbki końcowej. Należy również znormalizować metody badań oraz kwalifikacje personelu wykonującego i nadzorującego proces. Przestrzeganie określonych wymagań zapewnia system zarządzania jakością.

\section{System zarządzania jakością}

W celu zapewnienia wysokiej jakości w każdym momencie wytwarzania ważne jest wprowadzenie przez wykonawcę systemu zarządzania jakością.

W PN-EN ISO 14922:2002 Natryskiwanie cieplne - Wymagania jakościowe stawiane natryskiwaniu cieplnemu konstrukcji [19] podano ogólne wytyczne dotyczące zapewnienia jakości całemu procesowi natryskiwania cieplnego. W pierwszej części PN-EN ISO 14922-1: Wytyczne doboru i zastosowanie podano wskazówki, jak dobrać wymagania jakościowe stawiane natryskiwaniu cieplnemu, aby dopasować je do typu natryskiwanej konstrukcji. Norma zawiera trzy poziomy wymagań jakościowych stawianych natryskiwaniu cieplnemu, które opisano w kolejnych częściach: kompleksowe wymagania jakościowe (PN-EN ISO14922-2), standardowe wymagania jakościowe (PN-EN ISO 14922-3) i podstawowe wymagania jakościowe (PN-EN ISO 14922-4). W każdej z tych części określono wymagania jakościowe stawiane natryskiwaniu cieplnemu w warsztacie i na placu budowy. Podano wymagania dotyczące: umowy, natryskiwanej konstrukcji, personelu wykonującego i nadzorującego natryskiwanie cieplne, stosowanych urządzeń, wykonania natryskiwania, materiałów powłokowych, kontroli i badania procesu natryskiwania oraz świadectwa jakości.

Mgr inż. Anna Olbrycht - Instytut Mechaniki Precyzyjnej, Warszawa. 
Kompleksowe wymagania jakościowe (PN-EN ISO 14922-2) powinny być stosowane, gdy powłoka natryskiwana cieplnie musi sprostać zwiększonym wymaganiom. Ma to miejsce np. w lotnictwie, w energetyce lub w przemyśle chemicznym, wówczas gdy uszkodzenie powłoki może spowodować wysokie koszty lub nawet może stanowić niebezpieczeństwo dla ludności i środowiska. W tym przypadku wyrób musi spełniać wszystkie wymagania systemu zarządzania jakością od przeglądu umowy do zapisów dotyczących jakości w pełnym zakresie.

Jeśli nie jest wymagany tak wysoki system jakości, zleceniodawca i wykonawca mogą zawrzeć umowę, w której ustalone zostaną wymagania standardowe lub podstawowe. Ten sposób zalecany jest wówczas, gdy monitorowanie prac ma drugorzędne znaczenie na jakość natryskiwanej powłoki i jeśli ewentualne braki w produkcji nie spowodują wysokich szkód. Jedynie w dwóch przypadkach, tzn. w bezpieczeństwie pracy i ochronie środowiska oraz podczas składowania i postępowania z materiałami powłokowymi muszą być spełnione kompleksowe wymagania jakościowe.

\section{Kwalifikacje personelu}

Jednym z warunków zapewnienia wysokiej jakości i efektywności produkcji są wysokie kwalifikacje personelu. W tym celu opracowano PN-EN ISO 14918:2000. Natryskiwanie cieplne - Egzamin dla metalizatorów [15], w której określono sposób przeprowadzenia egzaminu dla metalizatorów i przedstawiono rodzaje egzaminów. Metalizator zdaje dwa egzaminy - egzamin teoretyczny z wiedzy zawodowej oraz egzamin praktyczny oceniający umiejętności metalizatora konieczne do natryskiwania cieplnego określoną metodą, sposobem natryskiwania (ręcznym lub zmechanizowanym), dla określonych zastosowań i przy zastosowaniu określonych materiałów powłokowych. W normie określono wiedzę jaką powinien posiadać metalizator, aby zdać egzamin teoretyczny oraz podano szczegółowe kryteria oceny w zakresie natryskiwania płomieniowego/natryskiwania łukowego cynkiem, aluminium i ich stopami jako ochrona przed korozją, natryskiwania płomieniowego/natryskiwania łukowego metalami i stopami w budowie maszyn, natryskiwania płomieniowego stopami przetapialnymi w budowie maszyn, natryskiwania plazmowego metalami i stopami w budowie maszyn, natryskiwania plazmowego cermetalami i węglikami, natryskiwania plazmowego ceramiką, natryskiwania płomieniowego-naddźwiękowego metalami i stopami oraz natryskiwania płomieniowego - naddźwiękowego cermetalami. Ponadto w normie określono czas trwania uprawnień metalizatora oraz przedstawiono wzór świadectwa z egzaminu dla metalizatora.

Oprócz wysokowykwalifikowanego personelu wykonującego proces natryskiwania cieplnego ważny dla zapewnienia wysokiej jakości produkcji jest odpowiednio wykwalifikowany personel nadzoru, którego zadaniem jest koordynacja wszystkich czynności związanych z natryskiwaniem cieplnym. Personel nadzoru jest odpowiedzialny za planowanie, wykonanie procesu, kontrolę i badanie. W PN-EN ISO 12690:2011 E Natryskiwanie cieplne - Nadzór nad natryskiwaniem cieplnym - Obowiązki i odpowiedzialność [14], która zastąpiła PN-EN 13214:2002 o tej samej nazwie, opisano zakres obowiązków i odpowiedzialności oraz sposób koordynacji czynności w celu zapewnienia wysokiej jakości powłok natryskiwanych cieplnie. Określono wiedzę techniczną, jaką powinien posiadać personel nadzorujący proces natryskiwania cieplnego. W załącznikach podano zalecenia dotyczące wymaganej wiedzy technicznej oraz zasadnicze czynności związane z natryskiwaniem cieplnym, którym można przypisać odpowiedni zakres obowiązków i odpowiedzialności.

\section{Badania odbiorcze urządzeń}

Kolejnym elementem wpływającym na jakość powłok natryskiwanych cieplnie są wymagania jakościowe stawiane urządzeniom do natryskiwania cieplnego. Poświęcona tym zagadnieniom jest, składająca się z siedmiu części, norma PN-EN 1395:2007 [4].

W PN-EN 1395-1:2007 określono wymagania dotyczące badania odbiorczego urządzeń do natryskiwania cieplnego, w tym urządzeń do natryskiwania płomieniowego z uwzględnieniem natryskiwania naddźwiękowego, urządzeń do natryskiwania łukowego, urządzeń do natryskiwania plazmowego $\mathrm{w}$ atmosferze i w komorach $\mathrm{w}$ warunkach kontrolowanych, jak również manipulatorów i podajników proszku stosowanych w procesach natryskiwania cieplnego. W normie podano cel i warunki badania odbiorczego, które uwzględnia wymagania techniczne stawiane urządzeniom i wymagania stawiane powłokom. W kolejnych częściach PN-EN 1395:2007 podano wymagania dotyczące badania odbiorczego poszczególnych urządzeń do natryskiwania cieplnego, stosowanych podczas wykonywania powłok natryskiwanych cieplnie o powtarzalnej jakości. W każdej części podano zasady badania odbiorczego, wykonanie badania odbiorczego oraz przedstawiono przykład protokołu badania odbiorczego. Zaleca się, aby części normy od 2 do 7 były stosowane łącznie z PN-EN 1395-1:2007, w której znajdują się wymagania ogólne i zasady postępowania.

Ważnym uzupełnieniem PN-EN 1395:2007 jest PN-EN 15339-2:2009 Natryskiwanie cieplne - Wymagania bezpieczeństwa dla sprzętu do natryskiwania cieplnego - część 2: Zespoły sterujące gazami [9], w której określono warunki bezpieczeństwa dla zespołów sterujących gazami, które służą do sterowania i/lub regulowania przepływu gazów w zamkniętym układzie regulacji. Ponadto przedstawiono działanie oraz konstrukcję zespołów sterujących gazami oraz wykaz norm zawierających wytyczne bezpieczeństwa. W załączniku podano przykłady konstrukcji zespołów sterujących gazami.

Obecnie w przygotowaniu znajdują się kolejne części PNEN 15339: Część 1: Wymagania ogólne, Część 3: Pistolety do natryskiwania cieplnego, ich połączenia i źródła zasilania, Część 4: Zasilanie paliwem gazowym i płynnym, Część 5: Podajniki proszku lub drutu.

\section{Materiały powłokowe, technologie, badanie powłok}

Poniżej przedstawiono krótkie opisy pozostałych norm poświęconych zagadnieniom wpływającym na jakość powłok natryskiwanych cieplnie. O zapewnieniu wysokiej jakości powłok natryskiwanych cieplnie decydują również takie czynniki jak: jakość materiałów powłokowych, monitorowanie całego procesu natryskiwania cieplnego - od przygotowania powierzchni do obróbki wykończeniowej oraz odpowiednie badanie powłok natryskiwanych cieplnie [25].

\section{Materiały powłokowe}

Istnieją dwie normy opisujące wymagania dotyczące dwóch podstawowych postaci materiałów powłokowych: proszków i drutów. PN-EN 1274:2007 Natryskiwanie cieplne - Proszki - Skład chemiczny - Techniczne warunki dostawy [3] zawiera właściwości i sposób określania właściwości proszków do natryskiwania cieplnego, składy chemiczne proszków oraz techniczne warunki ich dostawy. W PN-EN ISO 14919:2002 Natryskiwanie cieplne - Druty, pręty i żyłki do natryskiwania płomieniowego i łukowego - Klasyfikacja - Techniczne warunki dostawy [16] przedstawiono klasyfikację materiałów do natryskiwania cieplnego w zależności 
od: metody produkcji i wynikającej z niej struktury oraz grupy materiałowej i składu chemicznego. Podano wymiary i tolerancje drutów, prętów i żyłek, ich właściwości, zasady oznakowania oraz techniczne warunki dostawy.

\section{Technologie}

Do norm technologicznych zalicza się jedną z najważniejszych norm decydujących o prawidłowym wykonaniu i doborze powłok antykorozyjnych natryskiwanych cieplnie PN-EN ISO 2063:2006 Natryskiwanie cieplne - Powłoki metalowe i inne nieorganiczne - Cynk, aluminium i ich stopy [13]. W normie określono sposób przygotowania powierzchni przed natryskiwaniem, stosowane materiały powłokowe, warunki nakładania powłok oraz ich uszczelnianie i malowanie. Przedstawiono charakterystyczne właściwości powłok, metody ich badań oraz podano zalecane grubości powłok w zależności od warunków stosowania. Uzupełnieniem powyższej normy jest PN-H-04684:1997 Nakładanie powłok metalizacyjnych z cynku, aluminium i ich stopów na konstrukcje stalowe i wyroby ze stopów żelaza [24].

PN-EN ISO 14920:2000 Natryskiwanie cieplne - Natryskiwanie i przetapianie powłok ze stopów przetapialnych natryskanych cieplnie [17] dotyczy powłok natryskiwanych cieplnie, które jednocześnie lub bezpośrednio po natryskaniu zostają przetopione w celu wytworzenia jednorodnej powłoki związanej dyfuzyjnie z podłożem.

PN-EN ISO 17834:2006 Natryskiwanie cieplne - Powłoki do ochrony przed korozją i utlenianiem w podwyższonych temperaturach [22] dotyczy metalowych powłok natryskiwanych cieplnie stosowanych do ochrony przed korozją w temp. do $1000^{\circ} \mathrm{C}$. Zawarto w niej warunki wyboru materiału powłokowego oraz wymagania dotyczące natryskiwania powłoki.

PN-EN 15520:2008 Natryskiwanie cieplne - Zalecenia dotyczące zasad konstruowania części przeznaczonych do natryskiwania cieplnego [11] zawiera podstawowe zalecenia dotyczące projektowania części, które całkowicie lub tylko częściowo należy pokryć powłoką. Zaleca się je zarówno do części nowych, jak i regenerowanych. Decydujący wpływ na przyczepność powłoki natryskiwanej cieplnie ma przygo-

\section{Literatura}

[1] PN-EN 582:1996 Natryskiwanie cieplne - Określanie przyczepności metodą odrywania.

[2] PN-EN 657:2006 Natryskiwanie cieplne - Terminologia, klasyfikacja.

[3] PN-EN 1274:2007 Natryskiwanie cieplne - Proszki - Skład chemiczny - Techniczne warunki dostawy.

[4] PN-EN 1395:2007 Natryskiwanie cieplne - Badania odbiorcze urządzeń do natryskiwania cieplnego. Część 1: Wymagania ogólne. Część 2: Natryskiwanie płomieniowe z uwzględnieniem natryskiwania naddźwiękowego HVOF. Część 3: Natryskiwanie łukowe. Część 4: Natryskiwanie plazmowe. Część 5: Natryskiwanie plazmowe w komorach. Część 6: Manipulatory. Część 7: Podajniki proszku.

[5] PN-EN 13507:2010E Natryskiwanie cieplne - Przygotowanie powierzchni metalowych przedmiotów i części przed natryskiwaniem cieplnym.

[6] PN-EN 14616:2006 Natryskiwanie cieplne - Zalecenia dotyczące stosowania natryskiwania cieplnego.

[7] PN-EN 14665:2006 Natryskiwanie cieplne - Powłoki natryskiwane cieplnie - Symbole prezentowane na rysunkach.

[8] PN-EN 15311:2008 Natryskiwanie cieplne - Części z powłokami natryskiwanymi cieplnie - Techniczne warunki dostawy.

[9] PN-EN 15339-2:2009 - Natryskiwanie cieplne - Wymagania bezpieczeństwa dla sprzętu do natryskiwania cieplnego - Część 2: Zespoły sterujące gazami.

[10] PN-EN 15340:2008 Natryskiwanie cieplne - Oznaczanie odporności powłok natryskiwanych cieplnie na naprężenia ścinające.

[11] PN-EN 15520:2008 Natryskiwanie cieplne - Zalecenia dotyczące zasad konstruowania części przeznaczonych do natryskiwania cieplnego.

[12] PN-EN 15648:2011 Natryskiwanie cieplne - Opracowanie procedury pokrywania części.

[13] PN-EN ISO 2063:2006 Natryskiwanie cieplne - Powłoki metalowe $\mathrm{i}$ inne nieorganiczne - Cynk, aluminium i ich stopy.

[14] PN-EN ISO 12690:2011E Natryskiwanie cieplne - Nadzór nad natryskiwaniem cieplnym - Obowiązki i odpowiedzialność. towanie powierzchni części. W PN-EN 13507:2010E Natryskiwanie cieplne - Przygotowanie powierzchni metalowych przedmiotów i części przed natryskiwa-niem cieplnym [5], która zastąpiła PN-EN 13507:2002 o tym samym tytule, przedstawiono zasady stosowane podczas przygotowania powierzchni części metalowych przed natryskiwaniem cieplnym. Opisano metody przygotowania powierzchni oraz przedstawiono materiały ścierne stosowane przy obróbce strumieniowo-ściernej.

W PN-EN ISO 14924:2006 Natryskiwanie cieplne - Obróbka końcowa i wykończeniowa powłok natryskiwanych cieplnie [21] przedstawiono różne rodzaje obróbki mechanicznej, obróbki chemicznej oraz obróbki cieplnej powłok natryskiwanych cieplnie.

\section{Badanie powłok}

PN-EN ISO 14923:2005 Natryskiwanie cieplne - Charakterystyka i badanie powłok natryskiwanych cieplnie [20] zawiera charakterystykę powłoki natryskanej cieplnie oraz opis jej właściwości technologicznych i fizycznych. Przedstawia metody badań niszczących i nieniszczących stosowane powszechnie do badania powłok natryskiwanych cieplnie.

W PN-EN 582:1996 Natryskiwanie cieplne - Określanie przyczepności metodą odrywania [1] opisano badanie przyczepności powłoki natryskiwanej cieplnie do podłoża metodą odrywania w statycznej próbie rozciągania wykonywane w warunkach laboratoryjnych. W PN-EN 15340:2008 Natryskiwanie cieplne - Oznaczanie odporności powłok natryskiwanych cieplnie na naprężenia ścinające [10] opisano inną metodę badania przyczepności powłoki do podłoża: próbę ścinania. Próba ścinania służy do określenia przyczepności powłoki natryskanej cieplnie do podłoża (adhezja) i/lub wytrzymałości samej powłoki (kohezja) przy obciążeniu ścinającym. PN-EN ISO 17836:2006 Natryskiwanie cieplne - Wyznaczanie współczynnika osadzania powłoki natryskanej cieplnie [23] zawiera sposób oceny strat materiału powłokowego $\mathrm{w}$ procesie natryskiwania. Opisano kształt i wymiary próbek do badań oraz metodę wykonania badania. Podano sposób wyznaczenia współczynnika osadzania oraz informacje, które powinien zawierać protokół badania.

[15] PN-EN ISO 14918:2000 Natryskiwanie cieplne - Egzamin dla metalizatorów.

[16] PN-EN ISO 14919:2002 Natryskiwanie cieplne - Druty, pręty i żyłki do natryskiwania płomieniowego i łukowego - Klasyfikacja - Techniczne warunki dostawy.

[17] PN-EN ISO 14920:2000 Natryskiwanie cieplne - Natryskiwanie i przetapianie powłok ze stopów przetapialnych natryskanych cieplnie.

[18] PN-EN ISO 14921:2002 Natryskiwanie cieplne - Procedury stosowania powłok natryskiwanych cieplnie na części maszyn.

[19] PN-EN ISO 14922:2002 Natryskiwanie cieplne - Wymagania jakościowe stawiane natryskiwaniu cieplnemu konstrukcji. Część 1: Wytyczne doboru i zastosowanie. Część 2: Kompleksowe wymagania jakościowe. Część 3: Standardowe wymagania jakościowe. Część 4: Podstawowe wymagania jakościowe.

[20] PN-EN ISO 14923:2005 Natryskiwanie cieplne - Charakterystyka i badanie powłok natryskiwanych cieplnie.

[21] PN-EN ISO 14924:2006 Natryskiwanie cieplne - Obróbka końcowa i wykończeniowa powłok natryskiwanych cieplnie.

[22] PN-EN ISO 17834:2006 Natryskiwanie cieplne - Powłoki do ochrony przed korozją i utlenianiem w podwyższonych temperaturach.

[23] PN-EN ISO 17836:2006 Natryskiwanie cieplne - Wyznaczanie współczynnika osadzania powłoki natryskanej cieplnie.

[24] PN-H-04684:1997 Nakładanie powłok metalizacyjnych z cynku, aluminium i ich stopów na konstrukcje stalowe i wyroby ze stopów żelaza.

[25] Olbrycht A.: Normalizacja natryskiwania cieplnego, Inżynieria Powierzchni, $2014 \mathrm{nr}$ 4, s. 46-50.

[26] Milewski W., Olbrycht A.: Normalizacja procesów natryskiwania cieplnego w krajach UE. Stan obecny i perspektywy. Normalizacja,11, 2000, s. 7-10.

[27] Milewski W., Olbrycht A.: Standardization of the thermal spraying in the EU countries. The state of art and prospects. VI International Conference and Exhibition "Corrosion-2002", Lwów, 4-6.06.2002 r.

[28] Milewski W., Olbrycht A.: Normalizacja procesów nakładania metalowych powłok ochronnych. Międzynarodowe Seminarium "Normalizacja w ochronie przed korozją na tle wymagań Unii Europejskiej". Hajnówka, 25-27.06.2003 r. 